\title{
Imagens do feminino e do nacionalismo nas danças solo no Brasil: o bailado de Eros Volúsia e a performance de Luiz de Abreu $^{1}$

O artigo discute a importância e o impacto das danças solos de Eros Volúsia chamando a atenção para a operação "antropofágica" que esta realizou em sua dança em relação às referências culturais estrangeiras e as nacionais. Além de analisar as danças solos de Volúsia e a construção de um "bailado nacional" a partir da mestiçagem de elementos da cultura européia, negra e indígena, com ecos de uma ideologia política nacionalista vigente neste período histórico do Brasil, o artigo estabelece relações entre a pioneira solista moderna e o trabalho solo "Samba do crioulo doido", de Luiz de Abreu, um artista

brasileiro da atualidade na dança contemporânea, em sua crítica ao tema tão caro a Volúsia: brasilidade e, por extensão, a imagem da mulher brasileira relacionada à sensualidade e malevolência.

Palavras-chave: Dança solo; Eros Volúsia; Luiz de Abreu; Nacionalismo; Feminino.

\section{Abstract}

The article discusses the importance and impact of the Eros Volúsia's dance solos pointing to the "antropofágica" operation that held in their dance in relation to nationals and foreign cultural references. In addition to analyzing Volúsia's solo dances and her goal of constructing a "national bailado" based on the miscegenation of European, black, and indigenous cultural elements, with echoes of the nationalist political ideology dominant in this historic period in Brazil, the article establishes a relationship between this pioneer modern soloist and the solo "Samba do crioulo doido", by Luiz de Abreu, a Brazilian artist active in contemporary dance, who analyzes themes important to Volúsia: Brazilianness and, by extension, the image of

Brazilian women related to sensuality and malevolence.

Keywords: Solo dance; Eros Volúsia; Luiz de Abreu; Nationalism; Female.

\footnotetext{
1 Texto originalmente publicado no livro On stage alone - Soloists and the Modern Dance Canon. Editado por Claudia Gitelman e Barbara Palfy. University Press of Florida, 2012.

2 Pesquisadora e professora do Programa de Pós-Graduação em Teatro do Centro de Arte da UDESC.
} 
$\mathrm{N}$ as primeiras quatro décadas do século $\mathrm{XX}$ ocorreram inúmeras transformações na dança no ocidente, especialmente na Europa e na América do Norte, com reverberações em outros países da Ásia e da América do Sul. Um dos fenômenos mais importantes desta nova dança situava-se na composição solística de dançarinas, marcada pelas contribuições que oscilavam entre a dança "natural" de Isadora Duncan, a dança "de expressão" de Mary Wigman, a dança "espiritual" de Ruth Saint Denis e a dança "grotesca" de Valeska Gert. Entre as contribuições singulares das danças solo de cada uma destas mulheres criadoras ressalta-se a proposição de uma nova corporeidade e postura do feminino e o rompimento do discurso universal do corpo consolidado pela gramática do balé.

$\mathrm{O}$ ato de estar só em cena revela uma postura política, estética e ética e é visto comumente como uma figura própria da modernidade na dança (ainda que algumas sociedades arcaicas se utilizavam desta prerrogativa, como a balinesa). A dança individualizada torna-se uma constante nas primeiras décadas do século XX, sustentada por determinados pressupostos éticos e filosóficos, fundados nos princípios de que qualquer pessoa pode e deve dançar, sendo o movimento um caminho para conquistar a unidade psicofísica e a liberdade, e de que cada dançarino(a) pode encontrar sua dança natural e pessoal, dando forma à auto-expressão pelo movimento e ritmo ${ }^{3}$.

As propostas solísticas das primeiras dançarinas modernas diferenciavam-se em sua visão de uma nova dança por meio da absorção de modelos estéticos de outras culturas, tais como a grega em Isadora Duncan, a oriental em Ruth Saint Denis e a africana em Katherine Dunham. A estilização de danças no início do século XX a partir de culturas africanas, diferente da alteridade constituída por meio de um olhar utópico tardo-romântico para as culturas

\footnotetext{
3 A expressão era um conceito revolucionário para a época, enquanto manifestação corporal de impulsos e sentimentos internos. Com o intuito de acessar a "profundidade do corpo expressivo", Duncan renunciou ao espelho, prática comum nas aulas de balé porque este valoriza mais a imagem externa do que a interna (Daly, 1995, p.120).
}

grega, indiana ou egípcia, possuía uma implicação sócio-política latente, por conta da formação recente e de maneira conflituosa da identidade de países como o Brasil e os Estados Unidos.

No Brasil dos anos 1930 e 40 os solos de dança de Eros Volúsia (Rio de Janeiro, 1914-2004) afirmam-se numa mistura de nacionalismo e modernismo, imbuídos em refletir sua própria cultura, mais precisamente, a vertente afro-brasileira. Neste período, a arte brasileira afirmava questões relativas à cultura nacional, sem perder de vista o desejo de ser moderna. O movimento modernista desencadeado pela "Semana de 22", realizada em 1922, na cidade de São Paulo, por uma nova geração de intelectuais e artistas que criticavam as formas artísticas e literárias pautadas nas tradições do academicismo, deixou como herança a busca por uma consciência criadora nacional preocupada em retratar a cultura brasileira, das características naturais à crescente urbanização das metrópoles, em conexão com os movimentos das vanguardas européias.

Neste contexto, a nova dança preconizada por Volúsia volta-se para as matrizes afro-brasileiras, diferenciando-se de outras figuras da dança brasileira da época, cujo imaginário cinético ainda seguia a tradição do balé. No mesmo período - décadas de 1930 e 40, a antropóloga e bailarina americana Katherine Dunham (1909 - 2006) conhecida como a "mãe da dança negra" e fundadora da primeira grande companhia de dança moderna negra nos Estados Unidos em 1930 - construía sua visão singular da dança afro-americana, na sincrética, porém segregada cultura americana. Ambas trouxeram para a cena da dança moderna uma visão não eurocêntrica, representando a cultura afro-americana e afro-brasileira, respectivamente, em seus países de origem.

A proposição de criação de um corpo nacional em Eros Volúsia encontrava eco na ideologia política do governo brasileiro na época do Estado Novo, em duas frentes de atuação fundamentais deste: a cultura e a educação, buscando "assentar as bases 
da nacionalidade, edificar a pátria, forjar a brasilidade" (Pereira, 2003, p.275)4. Somente Eros Volúsia, numa quase unanimidade entre artistas, políticos e críticos teatrais da época, com seu corpo mestiço, alcançava o sincretismo e alçava o popular à condição de arte erudita. Considerada como a inventora do "bailado nacional", operou em suas danças solos e coletivas uma espécie de operação antropofágica em relação às referências culturais estrangeiras e as nacionais.

Neste artigo destaco o início dos solos de dança moderna no Brasil a partir do estudo de Roberto Pereira (1965-2009) sobre Eros Volúsia e o bailado nacional dos anos 1930 e 1940, bem como da noção de mestiçagem formatada pela proposta antropofágica filosófica e ética de Oswald de Andrade (1890-1954). O termo bailado, tradução do francês ballet, se firmava no momento em que o balé era institucionalizado no país, com a criação das primeiras escolas e companhias oficiais dos teatros das grandes cidades brasileiras. As danças solo de Eros Volúsia eram vistas pelos críticos teatrais da época como tipicamente brasileiras. A bailarina, coreógrafa e pesquisadora inseriu as danças populares brasileiras nos espaços de elite, tais como o Theatro Municipal do Rio de Janeiro, movendo partes do corpo intrínsecas à cultura corporal afrodescendente, impensáveis na estrutura do bailado acadêmico vigente. Neste sentido, sua dança afirmava uma outra imagem da mulher por meio de referências afro-brasileiras.

\section{A afirmação de uma cultura nacional}

A discussão sobre as questões nacionalistas no Brasil se intensifica no século XIX, quando se inicia a busca de uma identidade nacional. O fator racial estava sendo amplamente discutido, no momento em que ocorria um significativo contingente populacional vindo da Europa. Entretanto, a visão de miscigenação herdada do roman-

\footnotetext{
4 Para uma visão mais abrangente das relações entre a dança e as políticas culturais do Estado Novo, nome do regime político brasileiro fundado por Getúlio Vargas em 1937, ver a obra de Roberto Pereira (2003).
}

tismo idealizava a figura do índio e praticamente excluia o negro das formulações teóricas do pensamento brasileiro. Com o fim da escravidão no Brasil, decretada oficialmente em 13 de maio de 1888, através da Lei Áurea, o negro vai gradativamente aparecendo como personagem importante na dinâmica social brasileira.

A miscigenação brasileira será entendida, a partir de então, como o cruzamento da raça branca européia, do negro africano e do índio autóctone. No entanto, o europeu permanecia como o elemento civilizador por excelência. Segundo Renato Ortiz (1994), essa superação veio com o deslocamento, nos anos 1930, da idéia de raça para a de cultura, tese esta defendida na célebre obra do sociólogo Gilberto Freyre, Casa grande e senzala, publicada em $1933^{5}$. A consagração do mestiço como ente nacional por excelência ocorre, segundo Ortiz, a partir da reelaboração, feita por Freyre, das teses dos pensadores que o antecederam, entre eles Silvio Romero: [...] A ideologia da mestiçagem, que estava aprisionada nas ambiguidades das teorias racistas, ao serem reelaboradas passam a difundir-se socialmente e se tornar senso comum, ritualmente celebrado nas relações do cotidiano, ou nos grandes eventos como carnaval e o futebol. O que era mestiço torna-se nacional (Ortiz,1994, p.41).

Na década de 1920, na então capital do país, o Rio de Janeiro, havia uma valorização dos aspectos indicadores da identidade nacional, num esforço de ruptura com o Brasil colonial "atrasado". O país ansiava se fazer aceito no contexto civilizatório, empenhando-se em construir valores nacionais que respondessem ao mesmo tempo à afirmação de sua identidade e ao imaginário demandado pela modernidade, com seus referenciais de progresso urbano, interculturalidade e velocidade. Ser moderno, como detecta Velloso (1996, p. 31), era ser brasileiro.

\section{O gênero de teatro musical dominante}

5 Gilberto Freire (Recife, 1900 - 1987) assistiu a apresentação de Eros Volúsia pela primeira vez em Paris, numa apresentação desta no Cassino d'Enghien, em 1948 . 
nos palcos brasileiros no período de 1910 a 1940, o Teatro de Revista, consolidava o tipo mestiço da mulata. Os solos do Teatro de Revista eram dançados pelas vedetes, junto aos bailados das coristas, e apresentavam aspectos vistos pela sociedade carioca como modernos, buscando mesclar a tradição com ritmos brasileiros. Volúsia, que dançou no Teatro de Revista aos 35 anos, fez também o caminho inverso, levou as danças populares para os teatros da elite. Para aliar o popular e o erudito a artista realizou uma contundente pesquisa sobre danças populares brasileiras de diferentes regiões. Nas inúmeras conferências-demonstrações voltadas para pesquisadores, artistas e críticos, ela expunha de forma inovadora suas descobertas baseadas na pesquisa em museus e viagens de observação pelo país aliando à sua fala a apresentação de danças solo por ela criadas. ${ }^{6}$

As apresentações de Volúsia provocavam uma acalorada discussão nos jornais da época no Rio de Janeiro, com questionamentos acerca da brasilidade de sua dança, a sensualidade dos seus movimentos, bem como as suas conexões com o balé. Contudo, como salienta Roberto Pereira (2004), faltavam parâmetros analíticos para descrever a brasilidade no corpo da dançarina, para além dos "motivos brasileiríssimos" que tanto exaltava. Mario Nunes, em crítica endereçada à apresentação de Volúsia no bailado Uirapuru, com música de VillaLobos, questiona o ineditismo da mesma ao relacionar a dança desta a "algo já criado - o expressionismo", fazendo alusão aos movimentos da vanguarda européia recém assimilados pela cultura brasileira (Pereira, 2004, p.235).

A ausência de um acabamento técnico proveniente do balé - uma vez que este era a referência de arte maior, é um dos aspectos que dificultava o entendimento da proposição estética de Volúsia (Pereira, 2004). A diversidade das danças brasileiras

\footnotetext{
6 Uma das conferências mais marcantes foi a realizada em Paris, nos Archives Internationales de la Danse, a convite de seu diretor, Pierre Tugal, em 1948. Os jornais parisientes, como Le Matin, preconizaram: Eros será a segunda Isadora Duncan do século (Pereira, 2004,p.104).
}

pesquisadas por Volúsia impressiona, devido à extensão do país e suas diferentes manifestações culturais. Em seu livro Eu e a dança (1983) ela define suas coreografias como dramáticas, simbólicas e recreativas, estas impregnadas de uma grande dose de expressionismo. As recreativas teriam um caráter de entretenimento, as dramáticas teriam um visão trágico-satírica e as simbólicas um apelo fetichista ou religioso, a exemplo das danças "Macumba" e "Candomblé". O termo expressionismo parece carregar a idéia de uma visão subjetiva de Volúsia na representação dos "estados da alma" do povo brasileiro por meio das danças populares, conectando a arte da dança à uma modernidade recém-incorporada na cultura brasileira.

Entretanto, era possível perceber em algumas opiniões críticas publicadas o quanto a cultura negra e indígena era subestimada pelas elites, quando se tratava de pensar uma dança nacional, tendo o modelo europeu da alta cultura como norte. Segundo Mario Nunes, a dança de Volúsia ainda estaria no plano de "ensaio", a serviço de uma representação "primário e grosseira", "própria dos pretos e índios", carecendo de uma transposição de arte popular para arte erudita, algo que passaria do "sensualismo puramente sexual" para o "plano espiritual" (Apud Pereira, 2003, p. 235).

Eros Volúsia foi comparada no exterior a uma "Isadora Duncan tropical" ou a uma "exótica dançarina folclórica do Brasil", a exemplo de quando foi apresentada aos norte-americanos em sua turnê naquele país ${ }^{7}$. A invés de estabelecer uma comparação entre a dançarina brasileira e Duncan, como ocorreu em suas viagens à França e aos Estados Unidos, é mais prudente pensar numa analogia entre a aventura estética de Katherine Dunham e a de Eros Volúsia. As reações às coreografias de ambas, por parte do público e da crítica são, de certa forma, equivalentes. Dunham tentava

\footnotetext{
7 Na ocasião, Eros Volusia foi capa da Revista LIFE (22/09/1941), tendo sido uma das primeiras artistas sul-americana com "tal distinção", antes mesmo de Carmem Miranda, a quem Volúsia declara ter emprestado os movimentos sinuosos dos braços e mãos.
} 
"educar" os críticos e a audiência em seu país sobre o significado social das danças africanas e caribenhas, especialmente quanto aos sinuosos movimentos pélvicos. Não era fácil argumentar para uma América puritana o significado simbólico das tradições africanas, cujos movimentos são essencialmente provenientes da pélvis. Banes (1998, p.152-153) afirma que Rites de Passage, uma das obras mais emblemáticas de Dunham, incluía danças sociais e rituais haitianos, cubanos e brasileiros, bem como danças das plantações do sul dos Estados Unidos, que juntas formavam um caleidoscópio etnográfico.

É sabido que as sementes da nova dança do ocidente, a moderna, são lançadas principalmente por meio de uma alteridade orientalista imaginada. A ideia de um exotismo e de um corpo natural na dança moderna requer cuidados para não se perpetuar em generalizações. $\mathrm{O}$ imaginário relativo ao corpo natural/cultural de Duncan diverge do proposto por Dunham. Volúsia, por sua vez, também apresenta especificidades em sua corporeidade de inspiração afro-brasileira. Como observa Ann Dayle (1995), ainda que as danças de Isadora Duncan propusessem espontaneidade e liberdade, estavam longe de serem "selvagens" ou viscerais, no sentido atribuído a culturas ditas primitivas ou arcaicas. "Apesar de 'espontânea' seu estilo de movimento tinha um sentido de fluxo, uma gentileza sem pressa, em comparação com os "espasmos" ou "paroxismos" das danças modernas de inspiração africana" $[\ldots]^{8}$ (Daly, 1995, p.115). Dunham e Volúsia buscavam manter em suas pesquisas de dança movimentos mais próximos aos impulsos cinéticos e a visceralidade das danças africanas, mas, evidentemente, estilizando-as, cientes de que não seria possível reproduzir no palco os rituais estudados em seus respectivos trabalhos de campo.

8 "Although 'spontaneous' her movement style had a decided sense of flowing, unhurried gentility, compared with the "spasms" or "paroxysms" of the African-inspired modern dances" [...] (Daly, 1995, p.115)
Numa crítica ao espetáculo Batuque, Jayme de Barros critica a bailarina clássica Madeleine Rosay, visto que, embora com recursos técnicos, ela não alcançava o sincretismo da dança de Eros Volúsia. O gesto gracioso de Rosay seria uma caricatura das danças brasileiras, pois teria faltado "a estilização, a integração no motivo musical" e, finalmente, a "intuição artística, o sangue, a alma, a cor morena de Eros" (Barros Apud Pereira, 2003, p.249). As "contorções convulsivas", "próprias do espasmódico êxtase carnavalesco das garotas do morro" de Rosay não atingiam os níveis de abstração conquistados por Volúsia (Pereira, 2003, p.249). O trânsito entre o erudito-nacional-popular efetuado por Volúsia caracterizou um novo corpo para a dança em sua época. Um corpo que se fez mestiço precocemente, desde que Volúsia frequentava na infância os centros de umbanda no Rio de Janeiro. A artista iniciou os primeiros passos na dança, aos quatro anos de idade, em um terreiro localizado em frente à sua casa. Ela descreve sua iniciação: "Eu era garotinha quando entrei em contato com estranhas danças do ritual da macumba [...] Atraída por aqueles ritmos bárbaros, acabei tomando parte no cerimonial. Os crentes da macumba descobriram em meus olhos, em minha fisionomia, em meus gestos, uma força sobrenatural, e me submeteram ao batismo" (Volúsia apud Pereira, 2004, p. 22).

As "convulsões epiléticas" da umbanda apresentados por Volúsia, para críticos como Mário Nunes, deveriam ser transformadas em passos de dança, elevando para o plano espiritual os impulsos sensuais das toadas e danças de origem africana, a fim de transformá-la em arte superior. Em detrimento de críticas redutoras como as de Nunes, a arte de Volúsia começava a ser vista como genuinamente brasileira. Ainda que não houvesse um consenso na época que descrevesse o que seria esta brasilidade ou nacionalidade de sua dança, ela estaria associada irremediavelmente à composição mestiça da cultura brasileira. 


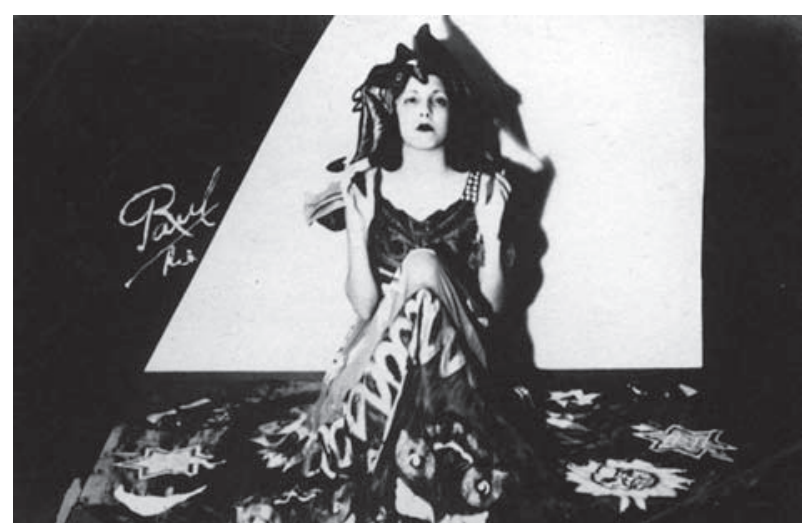

Eros Volúsia em No Terreiro de Umbanda, 1937. Foto de Raul. Cortesia da família de Eros Volúsia

\section{Primeiros passos do bailado nacional}

A primeira grande apresentação da criadora do bailado nacional foi num vesperal no Theatro Municipal do Rio de Janeiro, o espaço mais ilustre da cena brasileira, no dia 28 de setembro de 1929. Volúsia levava àquele palco nobre uma dança "tipicamente brasileira", onde descalça, dançava acompanhada de músicos tocando violão e batuques. O seu número apresentava um "samba típico baiano": Oia a fóia no a., de autoria de Aníbal Duarte de Oliveira. A ousadia da artista, "então incompatível como as tradições elitistas daquele palco", teve o silêncio inicial rompido pelo próprio presidente do país na época, Washington Luiz, que de pé, comandou uma salva de palmas (Pereira, 2004, p.27).

A comparação da proposta da dançarina a formas codificadas de dança seria equivocada, na visão de alguns críticos da época. Os bailados de Eros seriam para estes novidades, porque eram inéditos. $\mathrm{Ou}$ seja, ela não dançaria, segundo o crítico Int., do Diário de Notícias, "como os bailarinos russos. Dança como sente a arte brasileira. Não fica na ponta dos pés, mas seus gestos dizem tudo que pode dizer em matéria de arte" (Apud Pereira, 2003, p.236). Em entrevista a jornais brasileiros, Volúsia revela seu entendimento de arte como um processo híbrido, no qual referenciais arcaicos, clássicos e modernos podem se fundir: “[...] o clássico puro já não existe. Os bailarinos clássicos utilizam-se de todas as criações modernas, desde o materialismo das acrobacias, até a espiritualidade do expressionismo. A minha dança é um misto de clássico, moderno e folclórico, como é a dança universal atualmente, pois, como já disse, o bailado clássico já não existe mais depois de Isadora Duncan. (Apud Pereira, 2003, p.238).

Ciente da renovação trazida por dançarinas como Isadora Duncan, Volúsia miscigena elementos codificados provenientes da dança clássica e das danças populares de diferentes regiões do país pesquisadas in loco, tais como o samba, o lundu, o maxixe, o maracatu e movimentos de algumas nações indígenas. A criação de uma nova dança por Volúsia não ocorreu por conta de uma negação veemente do balé, como ocorreria com grande parte das dançarinas ícones da modernidade. Volúsia se propôs a realizar um movimento de devoração intercultural de referências tanto européias e americanas quanto brasileiras, tal qual a antropofagia oswaldiana enuncia, o que implica uma atitude de receptividade e de escolha crítica. Apesar de não utilizar estritamente passos de balé em seus solos, Volúsia valorizava seu aprendizado de quatro anos desta tradição na Escola de Bailados do Theatro Municipal do Rio de Janeiro. A tradição clássica funcionava como contraponto ao seu processo polifônico de criação de uma nova dança, sendo que chegou a dançar de forma pioneira nas pontas a coreografia "Tico-Tico no fubá", com a célebre música homônima de Zequinha de Abreu. Mesmo diante dos elogios da grande dama do balé no mundo, Anna Pavlova9', Volúsia não se restringiu ao ambiente acadêmico, como declararia:

\begin{abstract}
Embora suas palavras fossem de grande estímulo para mim, consagradoras mesmo, eu sentia que não podia me restringir ao método acadêmico, já que meu temperamento, 0 amor ao ritmo brasileiro e às danças que exprimiam estados de alma exigiam de mim maior campo de ação.
\end{abstract}

\footnotetext{
9 O fato ocorreu no ano de 1928, última ocasião em que Ana Pavlova veio com sua companhia ao Brasil e ano que marca o ingresso da jovem Eros Volúsia, então com 14 anos, na Escola de Bailados do Theatro Municipal do Rio de Janeiro (Pereira, 2004).
} 
Seria absurdo cultivar uma arte de expressão internacional, quando toda uma raça esperava de meu corpo a realização de sua alma. Minha tendência pelos ritmos brasileiros manifestou-se logo que iniciei meus primeiros passos de dança (Volúsia Apud Pereira, 2004, p. 24).

Publicado na "Revista Antropofagia" (1928), Manifesto Antropofágico pretendia recuperar metaforicamente uma crença de alguns povos indígenas antropófagos, que devoravam o inimigo supondo que assim estavam assimilando suas qualidades. O manifesto é considerado o mais radical de todos da primeira fase do Movimento Modernista, ao defender um projeto de resistência às incorporações feitas sem o devido senso crítico. A proposta era "devorar" a cultura e técnicas estrangeiras e submetê-las a uma digestão crítica em nosso estômago cultural, de forma a assimilá-las ou ainda vomitálas, se fossem consideradas impróprias ou indesejáveis. O conceito de antropofagia era uma maneira de reagir não só ao confronto constante com a cultura colonizadora, mas com processos de hibridização cultural no Brasil, provocados pelas sucessivas ondas de imigrantes durante sua história (Rolnik, 2005, p.57).

O escritor modernista Mário de Andrade, que se dedicou a pesquisar a música e a dança brasileira ${ }^{10}$, em sua crítica do trabalho de Volúsia, chama a atenção para a originalidade de sua dança, apartada do "velho classicismo com suas poses acadêmicas ou os pinotes vulgares da coreografia lírica" (apud Pereira, 2003, p. 126). A dança de Volúsia estava prestes a realizar a tão sonhada proposição antropofágica. A pesquisa de Volúsia não se enquadraria na noção de resgate cultural, a exemplo dos registros de Mário de Andrade em sua tentativa de garantir a originalidade das manifestações populares, como o próprio escritor ressaltara.

10 Mário de Andrade entre 1934 e 1944 escreveu a obra "Danças Dramáticas do Brasil", dividida em três volumes que reúne os seus estudos em relação à música popular, às danças e ao folclore brasileiro.
A artista buscava a transformação deste material em matéria prima para bailados nacionais, aliando o popular e o erudito, estilização esta cara à época e adotada pela música e pela literatura brasileira (Pereira, 2004, p.47) ${ }^{11}$.

Em um de seus solos mais emblemáticos, "Cascavelando", Eros Volúsia realiza uma trans-criação ${ }^{12}$ do poema "Samba" da escritora Gilka Machado, sua mãe, cujos elementos poéticos foram inspirados nas danças de terreiro brasileiras. Nessa coreografia a bailarina, na parte superior do tronco, faz gestos ondulantes que lembram o movimento das cobras ou das ondas do mar por meio de gestos sinuosos. $\mathrm{Na}$ parte inferior do tronco, nos quadris e nos pés, o movimento marca o ritmo do samba, compondo uma movimentação muito sensual (Silva, 2002). "Cascavelando" nos faz lembrar a visionária obra "A serpentina", de Loie Fuller, no que diz respeito à recriação da metáfora do movimento fluído relacionando-o ao de uma cobra, no caso daquela, a uma cascavel, natural do continente americano. O nome atribuído à nova dança de Fuller por seu empresário, Rud Aronson, não poderia ser mais significativo. $O$ termo serpentina remonta à meados do século XVIII, como uma nova teoria estética para as especificações dos caracteres de representação da paisagem, falando de uma "linha ondulosa", ou "linha de beleza", ou "linha serpentina", igualmente chamada de "linha da graça", por onde a pintura poderia organizar o espaço visual da natureza (Lista,1994, p. 88). O termo cascavelando, análogo à serpenteando, cujo traçado lembra os movimentos das serpentes, permeia o poema da mãe, Gilca, e a dança da filha, Eros. O poema enfatiza o ritmo e a corporalidade da mulher brasileira a partir de seus elementos mestiços e da

\footnotetext{
11 Como aponta Nestor Canclini (2003, p.218), é preciso situar a cultura popular dentro das relações sociais permanentemente mutáveis, em face das novas interações com a modernidade, numa crítica os aspectos ideológicos conservacionistas que buscam "resgatar" tradições supostamente inalteradas.

120 escritor Haroldo de Campos levantou a impossibilidade de uma tradução literal de um sistema simbólico para outro usando o conceito de trans-tradução, ou transcriação, como uma forma de tradução criativa, uma reinvenção da cultura do outro, aproximando a antropofagia oswaldiana da poesia concreta.
} 


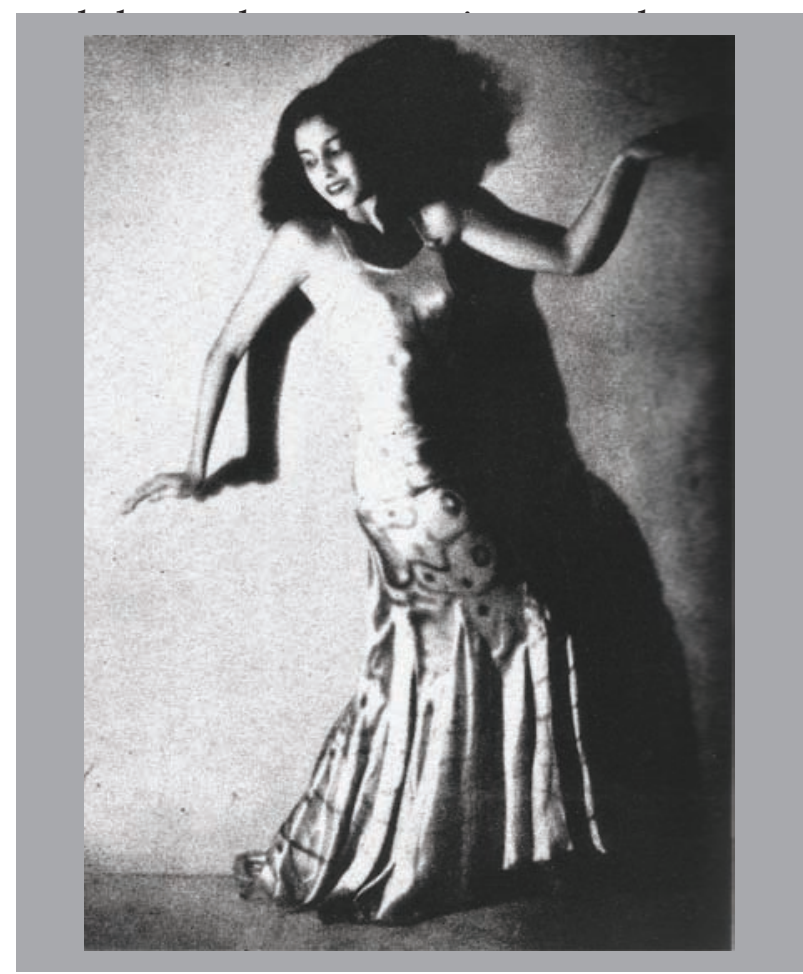

Eros Volúsia em Cascavelando, Fotógrafo desconhecido. Cortesia da família de Eros Volúsia.

E é exatamente a crítica à esta imagem cristalizada e extenuante - da sensualidade da mulata brasileira, bem como à questões sociais e políticas ligadas a negritude que motivará, seis décadas mais tarde, a pesquisa de um artista da dança contemporânea brasileira: Luiz de Abreu $^{14}$. A apologia a esta identidade corpórea sinuosa e sensual da mulher brasileira, especialmente a da negra e da mestiça, propiciou a longo prazo o surgimento de padrões que limitaram a leitura da complexidade cultural brasileira e os processos de subjetivação da mulher.

\section{A desconstrução no "Samba do crioulo doido"}

"Samba do crioulo doido" é uma criação solo de 2004 onde Luiz de Abreu discute a forma com que a sociedade brasileira vê o negro na construção da identidade

\footnotetext{
13 "Mexendo com as ancas, batendo com os pés, trementes os seios, virados os olhos, os dentes espiando a todos e a tudo, brilhantes, brilhantes, por dentro dos lábios;- creoula ou cafuza, cabocla ou mulata, mestiça ou morena - não te ama sómente quem nunca te viu dançando, sambando, nas noites de lua, mulher do Brasil!" (Machado. Sublimação, 1938).

14 Nasceu em Araguarí em 1963, onde realiza seu primeiro contato com a dança por meio da umbanda; vive e trabalha entre São Paulo e Salvador. Em meados dos anos 90 viaja a São Paulo, onde começa sua carreira solista. Atualmente aprofunda suas investigações sobre 'corpo negro'.
}

brasileira. Ele retoma um antigo samba homónimo criado em 1968, em plena ditadura militar, de autoria do escritor Sérgio Porto, que mistura ironicamente fatos da história, respondendo a um antigo decreto governamental, dos tempos de outra ditadura, a de Getúlio Vargas, o qual obrigava os compositores a criarem sambas sempre de cunho histórico sobre o Brasil.

No solo com duração de vinte e cinco minutos, Abreu ataca frontalmente os discursos nacionalistas que permitem um entendimento da corporeidade negra brasileira por meio da representação de certos estereótipos, como a comercialização de seu erotismo. A bandeira do Brasil é exposta todo o tempo, assim como o corpo nu do intérprete. No caso de Abreu, a criação do trabalho não se destina a perseguir uma dança nacional, mas a trabalhar criticamente com a noção de brasilidade e negritude.

A questão mais eminente de artistas na contemporaneidade parece não se voltar à criação de uma dança nacional, mas, como salienta Micheline Torres, de pensar como "fazer dança contemporânea no Brasil", de "como criar suportes para criação, circulação, pesquisa e formação de platéia" ${ }^{15}$. No texto "Cinco questões para pensar nas danças contemporâneas brasileiras como anticorpos à categoria tradicional de corpo brasileiro", Christine Greiner chama a atenção para o fato de que as práticas instigantes dos artistas da dança contemporânea mais atuantes no país funcionam como "anticorpos" à noção de dança brasileira "como um conceito em geral ou um bloco monolítico referencial" (Greiner, 2007, p.14). A marca de brasilidade que muitos destes artistas por ventura apresentem, grande parte inseridas em trabalhos solos, estaria mais voltada aos fluxos de sentido que se organiza nas experiências estéticas destes do que a regras a priori e coerentes com a imagem que se faz da dança brasileira ou do corpo brasileiro, seja no Brasil ou fora deste, conclui Greiner.

\footnotetext{
15 Entrevista à revista americana Scene4. Micheline Torres atuou por 12 anos na Lia Rodrigues Companhia de Danças como dançarina e assistente. Desde 2000 ela assumiu seu próprio trabalho solo, situado entre a dança, a performance e as artes visuais.
} 
A investigação de Volúsia traduzia o pensamento de dança e de cultura conectado à sua época, " com noções ao mesmo tempo românticas e nacionalistas do corpo e do bailado que pretendiam ser brasileiros » (Pereira, 2004, p. 46). Sua ideologia era um manifesto radical legítimo e legitimado contra o «vozerio estrangeiro que abafava o verbo da nacionalidade» das recém-descobertas artes brasileiras:

Passar do aparente imaterialismo dos bailados clássicos às humanísticas danças brasileiras, sangrentas ainda das tragédias do cativeiro e do exílio, quentes ainda do contato com a terra, é sem dúvida chocante à sensibilidade de qualquer público, principalmente quando este se encontra turbado de preconceitos que deseja ocultar para esquecer, quando este age sugestionando pelo «nacionalismo cosmopolita», quando este se encontra viciado à comodidade de assistir ou reproduzir as velharias importadas. [...] O Brasil está descobrindo a si mesmo, está finalmente se encontrando ${ }^{16}$.

O contato de muitos artistas brasileiros de dança contemporânea com certa produção estrangeira, especialmente a européia, tem reaquecido o debate acerca das implicações de um discurso colonizador-colonizado, mais do que a preocupação em buscar uma identidade cujo parâmetro seja a afirmação da cultura brasileira. Num contexto dito globalizado, estes artistas têm exercitado criticamente a apropriação de procedimentos artísticos de sua própria cultura e da cultura de outros países, desenvolvendo pesquisas mediadas por questões próprias, cientes dos inevitáveis processos de mestiçagem e hibridização de nosso tempo.

Serge Gruzinski, em «O pensamento mestiço» (1999), reconhece a impossibilidade de distinguir uma cultura pura. Segundo ele, todas as épocas de-

16 Conferência - manifesto realizada em 1939, no Teatro Ginástico, onde iniciaria sua atuação como professora (Pereira, 2004, p.46) ram lugar à mistura de culturas, sendo esta mesclagem um elemento constitutivo que enriquece, dinamiza e funda a criatividade das culturas, ao contrário da hegemonia ou imperialismo cultural. Os inevitáveis rasgos de fronteiras e suas conseqüentes hibridações levaram Canclini (1997) a concluir que todas as culturas, de certa forma, hoje (ou desde sempre), são de fronteira, a partir da idéia de que as artes se desenvolvem em relação com outras artes. O hibridismo opera enquanto deslocamento de valor, levando o discurso dominante a descentraliza-se e desviar-se (Bhabha, 2003). Não possui necessariamente uma perspectiva de profundidade ou verdade, a diferença das culturas não é resultante de um jogo dialético, mas é construída agonisticamente na fronteira.

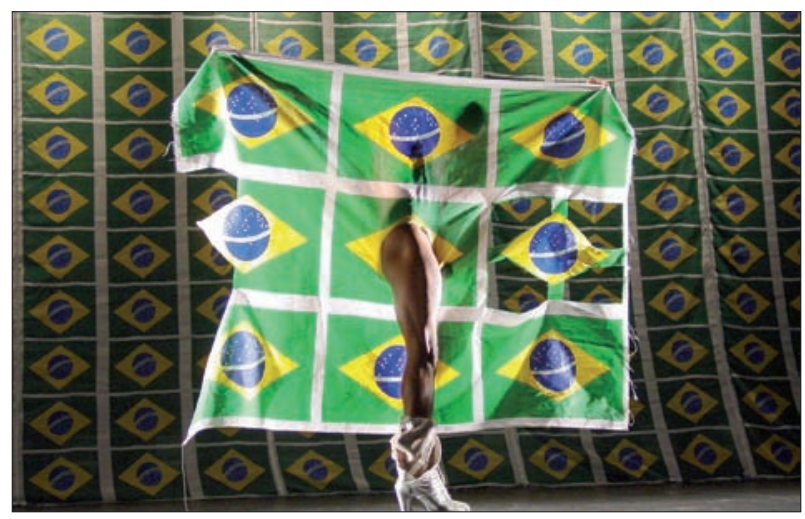

Luiz de Abreu em Samba do crioulo doido.

Foto: Gil Grossi. Cortesia do autor.

O olhar ético e político para o seu próprio país é uma constante da produção mais recente da dança contemporânea brasileira, ausente, contudo de uma utopia nacionalista. Sendo uma óptica diferenciada para a relação entre o local e o universal, a devoração intercultural, tal qual a antropofagia pensada por Oswald de Andrade, não seria uma atitude passiva ou impositiva do colonizado, mas uma escolha crítica. Na obra "O samba do crioulo doido" a devoração se dá por meios das imagens impostas aos negros em anos de história, estas facilmente consumidas pelo olhar estrangeiro. A operação antropofágica se faz presente em Abreu (2006): 
Eu acredito na mestiçagem da dança. Acho que é impossível estar no mundo e ter um trabalho completamente original, de você só na sua cultura. No Brasil temos um termo que é a antropofagia que vem dos índios. Eles achavam que se se comesse a pessoa, pegar-se-ia o poder dessa pessoa. Não era para se alimentar mas para ficar com o espírito e a ideia. A gente traz isso na cultura desde que o Brasil é Brasil. Nós desde sempre que estamos globalizados. Como não pensar isso se nós temos cultura vinda dos índios, da África, de Portugal, alemães... Eu acho que não tem que ter fronteira. $\mathrm{O}$ meu trabalho é do tamanho do meu corpo. A fronteira está em mim. [...] Tudo bem, mas há a questão da experiência que é impossível passar. É pessoal, está à flor da pele. É da pele. O limite do meu trabalho é o meu corpo, com todas as informações que estão no mundo.

Em "Cascavelando", Eros Volúsia, samba sensualmente revelando as formas do corpo com um vestido colante que imita o couro de uma cobra. É pura exaltação à uma recém-descoberta identidade brasileira. No "Samba do crioulo doido", Luiz de Abreu samba nu portando somente botas prateadas de saltos e cano alto. Abreu não reivindica uma dança nacional. Trata-se de outro contexto representacional, onde a mimises desta dança sinuosa e serpenteada "tipicamente brasileira" - utilizando um termo frequente na leitura da obra de Eros Volúsia - é subvertida. Flertando com a performance o samba de Abreu denuncia a banalização do corpo, um corpo-objeto que se fez produto de exportação mady in Brazil. O espetáculo trata da resistência do negro e dos significados do seu corpo na construção de sua identidade na história brasileira. Em "Samba do crioulo doido" as ondulações abdominais e os volteios do quadril que dança samba são performados ao som da voz rouca da cantora brasileira Elza Soares, cuja letra repete exaustivamente o seguinte refrão: "a carne mais barata do mercado é a carne negra". Nas palavras de Abreu (2006): “[...] Eu falo de mim mas também do ser humano, porque o gesto é uma coisa comum. Mas eu também não quero fazer uma dança nacional. Eu uso símbolos nacionais porque talvez o Brasil seja um dos poucos países em que o assunto do dia, tanto na Academia como no botequim, é o Brasil, é a identidade".

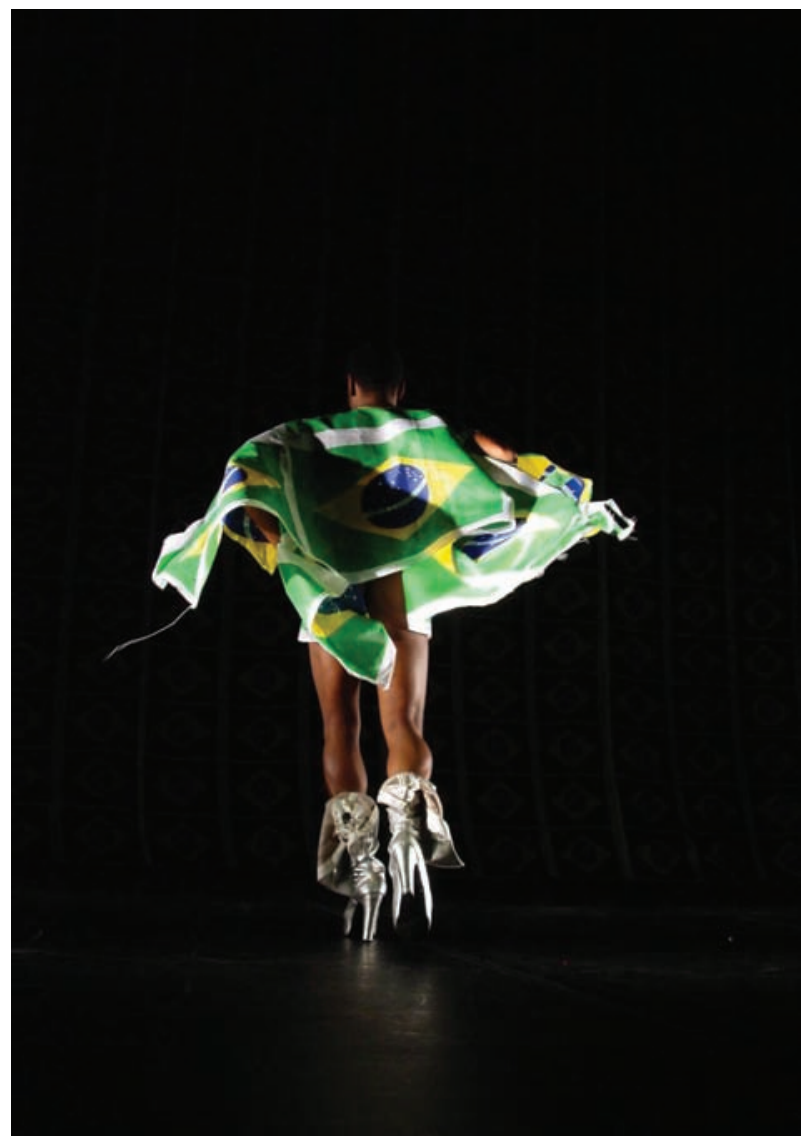

Luiz de Abreu em Samba do crioulo doido.

Foto: Gil Grossi. Cortesia do autor.

O samba do crioulo doido critica a reificação da figura da mulata. A ironia fina e a agudeza da performance de Luiz de Abreu é dispositivo político potente, fazendonos perceber nosso "olhar enviesado", como declararia o sociólogo Milton Santos (2000)," 17

17 "Ser negro no Brasil é, pois, com frequência, ser objeto de um olhar enviesado. A chamada boa sociedade parece considerar que há um lugar predeterminado, lá em baixo, para os negros e assim tranquilamente se comporta. Logo, tanto é incômodo haver permanecido na base da pirâmide social quanto haver "subido na vida'" (Santos, 2000). 
O solo discute a inter-relação entre 0 corpo-objeto construído pela diáspora e o corpo-sujeito que transgride, afirma e resiste, cria uma corporeidade que devolve ao corpo-objeto o sujeito que the foi extirpado ao longo da história, junto com sentimentos, valores, crenças, a palavra e suas singularidades estéticas. Samba, carnaval e erotismo constituem elementos aos quais o corpo negro brasileiro geralmente é associado. ${ }^{18}$

Num ponto de vista ideológico, o solo de dança, como aponta Cassini Ropa (2009), é o lugar irrenunciável e urgente da pessoa e da personalidade, em toda a sua singularidade; o lugar da revelação do imaginário e das memórias e sentimentos individuais. Esta postura pode ser entendida como uma crítica à ideologia social e política da coralidade induzida e uniformizada das massas. Mas as escolhas aparentemente individuais de Volúsia, assim como de outras figuras da modernidade, potencializa forças coletivas. Um solista age como se estivesse só ou separado, mas sua aparente solidão ecoa conexões múltiplas, a sua subjetividade se converte em um eco do coletivo. A subjetividade nunca é solitária (Schneider, 2002, p.86). O solo seria como se fosse o múltiplo do uno, a incarcanação da multiplicidade por um só corpo. Se Duncan evocava em si o espírito do coro grego, sustentado por princípios universais, Volúsia, por sua vez, entendia sua arte como a essencialização da alma mestiça do povo brasileiro. Luiz de Abreu, por outro lado, em um cenário composto por bandeiras brasileiras, constrói imagens que questionam o corpo objetificado. Trata-se de dois momentos distintos da dança solo no Brasil, cuja relação com o tema nacionalismo, gênero e brasilidade diferem, mas que se encontram legitimados, em suas devidas épocas e contextos, a partir de uma digestão crítica da sociedade brasileira.

18 Email de Luiz de Abreu à Victoria Noorthoorn, em 26 de maio de 2009. http://www. fundacaobienal.art.br/7bienalmercosul/pt-br/subversao-de-estereotipos-e-convencoes. 


\section{REFERÊNCIAS}

ABREU, Luiz de. Entrevista para Victoria Noorthoorn, 16 de maio de 2009. Disponível em http://www.fundacaobienal.art.br/7bienalmercosul/pt-br/subversao-de-estereotipos-e-convencoes. Acesso em 10 jan. 2011.

ABREU, Luiz de. O meu trabalho é do tamanho do meu corpo. Entrevista à Tiago Bartolomeu Costa em 06/06/2006. Disponível em http://omelhoranjo.blogspot.com/2006/06/naprimeira-pessoa-ii-luiz-de-abreu.html Acesso em 10 jan. 2011.

BANES, Sally. Dancing Women: Female Bodies on Stage. New York: Routledge, 1998.

BHABHA, Homi. O local de cultura. Belo Horizonte: UFMG, 2003.

CANCLINI, Néstor. Culturas Híbridas: estratégias para entrar e sair da modernidade. São Paulo: Edusp, 1997.

DALY, Ann. Done into Dance: Isadora Duncan in America. Middletown: Wesleyan University Press, 1995.

FREIRE, Gilberto. Sobrados e mucambos: decadência do patriarcado rural e desenvolvimento do urbano. 2 ed. Rio de Janeiro: José Olympio, 1951.

GREINER, Christine. Cinco questões para pensar nas danças contemporâneas brasileiras como anticorpos à categoria tradicional de corpo brasileiro. In: NORA, Sigrid (org.). Húmus n.2. Caxias do Sul: SESC, 2007.

GRUZINSKI, S. La Pensée métisse. Paris: Fayard, 1999.

LISTA, Giovani. Loie Fuller. Danseuse de la Belle Époque. Paris: Éditions d'Art.1994.

MACHADO, Gilka. Sublimação. Rio de Janeiro: Ed. Biblioteca Von-Hager-Gintner, 1938.

MEYER, Sandra. Modernity and Nationalism in Solo Dance in Brazil: The Bailado of Eros Volúsia and the Performance of Luiz de Abreu. In: GITELMAN, Claudia e PALFY, Barbara (org.) On Stage Alone - Soloists and the Modern Dance Canon. Gainesville: University Press of Florida, 2012.

ORTIZ, Renato. Cultura brasileira e identidade nacional. São Paulo: Brasiliense, 1994.

PEREIRA, Roberto. A formação do Balé Brasileiro. Rio de Janeiro: Editora FGV, 2003.

. Eros Volúsia. A criadora do Bailado Nacional. Rio de Janeiro: Relume

Dumará: RIOARTE, 2004.

ROLNIK, Suely. Anthropophagie Zombie. Paris: Mouvement, no. 36-37, 2005. 
ROPA, Eugenia Cassini. O solo de dança no século XX: Entre proposta ideológica e estratégia de sobrevivência. In: Revista Urdimento, Programa de Programa de Pós-Graduação em Teatro. Florianópolis: PPGT/UDESC, n. 12, 2009.

SANTOS, Milton. Ser negro no Brasil hoje. Ética enviesada da sociedade branca desvia enfrentamento do problema negro. 2000. Disponível em: http://www.ige.unicamp. br/ lmelgaco/santos.htm. Acesso em15 mar.2012.

SCHNEIDER, Rebecca. Unbecoming solo. IN: ROUSIER, C. (Org.). La danse en solo: une figure singulière de la modernité. Pantin: Centre National de la danse, 2002.

SILVA, Soraia Maria. A Criadora do balé brasileiro. Correio Braziliense. 26/02/2002. Disponível em www2.correioweb.com.br. Acesso em 10/01/2011.

VELLOSO, Monica. Modernismo no Rio de Janeiro. Rio de Janeiro: Ed. Fundação Getulio Vargas, 1996.

VOLÚSIA, Eros. Eu e a Dança. Rio de Janeiro: Revista Continente Editorial, 1983.

TORRES, Micheline Torres. Entrevista para American Magazine Scene4. Disponível em: http://www.sweetandtender.org/wiki/index.php?title=Micheline_Tor-res. Acesso em 10 fev. 2010. 
